\title{
THE OXEN
}

Christmas Eve, and twelve of the clock.

'Now they are all on their knees,'

An elder said as we sat in a flock

By the embers in hearthside ease.

We pictured the meek mild creatures where

They dwelt in their strawy pen,

Nor did it occur to one of us there

To doubt they were kneeling then.

So fair a fancy few would weave

In these years! Yet, I feel,

If someone said on Christmas Eve,

'Come; see the oxen kneel

'In the lonely barton by yonder coomb

Our childhood used to know,'

I should go with him in the gloom,

Hoping it might be so. 